Jusmal lemiah

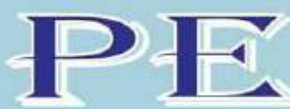

Vol. 10, No. 1, January 2022
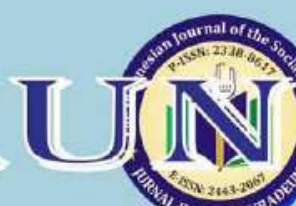

\section{Clarivate Analytics}

Emerging Sources Citation Index

Web of Science ${ }^{\mathrm{TM}}$

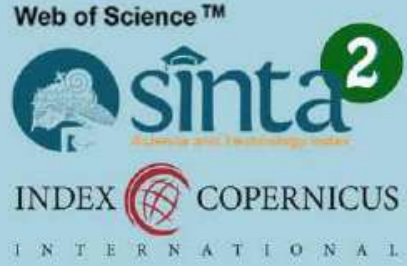




\author{
JURNAL ILMIAH PEURADEUN \\ The Indanesia Journal of the Sacial Sciences \\ p-ISSN: 2338-8617/ e-ISSN: 2443-2067 \\ www.journal.scadindependent.org
}
Vol. 10, No. 1, January 2022
Pages: 65-86

\title{
The "Teras Dakwah" (Dakwah Terrace) Movement Program: the Philosophy and Dakwah Activism Charity-Based in Yogyakarta
}

\author{
Masduki'; Dony Arung Triantoro'; ${ }^{2}$ Imron Rosidi ${ }^{3}$ \\ 1,2,3 Universitas Islam Negeri Sultan Syarif Kasim Riau, Indonesia
}

\begin{abstract}
Article in Jurnal Ilmiah Peuradeun
Available at : https://journal.scadindependent.org/index.php/jipeuradeun/article/view/624

DOI : https://dx.doi.org/10.26811/peuradeun.v10i1.624
\end{abstract}

\author{
How to Cite this Article \\ APA : Masduki., Triantoro, D. A., \& Rosidi, I. (2022). The “Teras Dakwah” (Dakwah Terrace) Movement \\ Program: the Philosophy and Dakwah Activism Charity-Based in Yogyakarta. Jurnal Ilmiah \\ Peuradeun, 10(1), 65-86. https://dx.doi.org/10.26811/peuradeun.v10i1.624
}

Others Visit : https://journal.scadindependent.org/index.php/jipeuradeun

\begin{abstract}
Jurnal Ilmiah Peuradeun (JIP), the Indonesian Journal of the Social Sciences, is a leading peer-reviewed and open-access journal, which publishes scholarly works, and specializes in the Social Sciences that emphasize contemporary Asian issues with interdisciplinary and multidisciplinary approaches. JIP is published by SCAD Independent and published 3 times of year (January, May, and September) with p-ISSN: 2338-8617 and e-ISSN: 2443-2067. Jurnal Ilmiah Peuradeun has become a CrossRef Member. Therefore, all articles published will have a unique DOI number. JIP has been accredited by the Ministry of Education, Culture, Research, and Technology, the Republic of Indonesia through the Decree of the Director-General of Higher Education, Research and Technology No. 164/E/KPT/2021, date December 27, 2021. This accreditation is valid until the January 2026 edition.
\end{abstract}

JIP published by SCAD Independent. All articles published in this journal are protected by copyright, licensed under a CC-BY-SA or an equivalent license as the optimal license for the publication, distribution, use, and reuse of scholarly works. Any views expressed in this publication are the views of the authors and not of the Editorial Board of JIP or SCAD Independent. JIP or SCAD Independent cannot be held responsible for views, opinions and written statements of authors or researchers published in this journal. The publisher shall not be liable for any loss, actions, claims, proceedings, demand, or costs or damages whatsoever or howsoever caused arising directly or indirectly in connection with or arising out of the use of the research material. Authors alone are responsible for the contents of their articles.

JIP indexed/included in Web of Science, MAS, Index Copernicus International, Sinta, Garuda, Moraref, Scilit, Sherpa/Romeo, Google Scholar, OAJI, PKP, Index, Crossref, BASE, ROAD, GIF, Advanced Science Index, JournalTOCs, ISI, SIS, ESJI, SSRN, ResearchGate, Mendeley and others. 


\title{
THE "TERAS DAKWAH" (DAKWAH TERRACE) MOVEMENT PROGRAM: THE PHILOSOPHY AND DAKWAH ACTIVISM CHARITY-BASED IN YOGYAKARTA
}

\author{
Masduki ${ }^{1}$; Dony Arung Triantoro ${ }^{2}$; Imron Rosidi ${ }^{3}$ \\ 1,2,3 Universitas Islam Negeri Sultan Syarif Kasim Riau, Indonesia \\ ${ }^{1}$ Contributor Email: masduki@uin-suska.ac.id
}

\begin{abstract}
Dakwah in Indonesia has been growing nowadays. It is seen from the presence of preachers (da'i) and dakwah institutions and organizations in Indonesia. This article contributed to the discourse of dakwah and charity in Indonesia, especially in the social institution of Teras Dakwah in Yogyakarta. In this context, the discourse about dakwah and charity has not been much studied by previous scholars. Most studies on dakwah focus on the figure, institution, oral and written dakwah, social media, and others. The main research proposed was why and how the Teras Dakwah has been involved in charity practices in both local and regional domains. The research data were obtained based on the nethnographic study. This research showed that the involvement of the Teras Dakwah in dakwah activismbased charity was influenced by the uncertain discourse of social guarantee from the government in which in turns the Teras Dakwah was involved in providing the religious social service both local areas in Yogyakarta and regional areas outside Yogyakarta.
\end{abstract}

Keywords: Dakwah Charity; Social Media. 


\section{A. Introduction}

This article discusses the dakwah movements that lead to social services in Indonesia. The study of Islamic dakwah in Indonesia has been widely written by several scholars; starting from studies of dakwah that focus on movement or community (Hasan, 2007; Kailani, 2012; Triantoro, 2018), dakwah media (Schulz, 2012; Sofjan, 2012; Sofjan, D., \& Hidayati, 2013; Sunarwoto, 2012), dakwah and politics (Rosidi, 2021) and studies on propaganda that emphasize the figure of an Ustaz (dai) (Hoesterey, 2008); (Watson, 2005); (Weng, 2018).

In contrast to the focus of existing scholarship studies, this article examines the propaganda activism that focuses on the social service of the community (charity). Although (Nasor et al., 2019) explain community empowerment done by BMT, he does not focus on dakwah conducted by a social institution like the Dakwah Terrace. The focus of this study is discussed through case studies at the Dakwah Terrace institute in the city of Yogyakarta. The Dakwah Terrace actively holds Islamic studies in Yogyakarta. They facilitate young Muslims in Yogyakarta to increase their Islamic knowledge through invited clerics. Islamic studies conducted by the Teras Dakwah are very diverse, ranging from the study of religion, economics to issues such as popular teen romance and others (Triantoro, 2018). Later, the Teras Dakwah is also actively involved in providing social assistance services to people in Yogyakarta and other cities in Indonesia as shown in the caption quote above.

This article argues that charity-oriented propaganda activism is a new propaganda trend in the dynamics of the Contemporary Islamic dakwah movement in Indonesia. In addition, this article shows that current charity practices are not only carried out by philanthropic institutions such as the National Amil Zakat Agency (BAZNAS), Amil Zakat Institutions (LAZ), Dompet Dhuafa, Ummat Care Justice Post (PKPU), or alms communities such as Alms node, Alms Street and Alms Group, which is very massive in Yogyakarta.

Specifically, this article discusses three questions. First, why is the dakwah movement involved in the discourse of generosity in Indonesia? Second, how is the Dakwah Terrace involved in the practice of charity in the 
local realm and other regional areas? Third, how does the Dakwah Terrace promote the idea of charity through social media?

To answer these questions, the structure of this article is divided into five parts. In the first part, this article explains the background that is the focus of this article. The second part explains the discourse of generosity in Indonesia and the current involvement of the dakwah movements. The third section discusses how the Dakwah Terrace carries out philanthropic programs. Fourth, this article examines how the Dakwah Terrace uses social media as a means of promoting the idea of charity and building an image. In the last part, this article provides conclusions and recommendations for future study.

\section{B. Method}

This article is a netnographic study. Referring to Kozinet (2010), netnography is the collection of data by following and tracing activities in an online space. This means that this article is not conducted through offline activities but online ones. This is because the fact that, during the research done, the researchers were unable to follow, observe and interview physically due to the COVID-19 pandemic. Using a netnographic study was useful to avoid the health risk caused during the covid 19 pandemic as well as it was appropriate to answer the research questions proposed. In the first stage, the research was done intensively by observing the online activities of the Teras Dakwah.

The researchers collected the data from two social media owned and managed by the Teras Dakwah. Specifically, the research data was obtained through social media of Instagram of @terasdakwah account and Facebook, in the form of image posts, videos, captions, and others. The second stage was done by clarifying the data obtained based on previous research conducted by the researchers. The data clarification was also conducted by interviewing the social media account holders of the Teras Dakwah. Then the researchers analyzed the research findings based on the academic discourse regarding preaching and charity written by 
previous scholars. After the research findings are dialogued with theoretical arguments from previous scholars, in the end, this study finds significant arguments, be they criticizing, corroborating, or having discoveries from previous scholars.

\section{Result and Discussion}

1. Result

\section{a. The Landscape of Islamic Generosity in Indonesia}

The significant development of the emergence of Islamic philanthropic institutions in Indonesia can be examined during the Soeharto era. The development ideology promoted by the New Order shows that the Soeharto government paid attention to the handling of poverty in Indonesia, especially at the end of its leadership, between 19971999. In the span of two years (1997-1999), the poverty rate in Indonesia has increased from 15\% to 33\% (Sakai, 2012).

During the Soeharto era, the task of handling poverty was left to the National Development Planning Agency (Bappenas), without involving the private sector. The government's emphasis on dealing with social welfare issues at the time lay in the economic growth strategy. However, in turn, this strategy was unable to deal with the brunt of the monetary crisis at the end of Suharto's leadership. Since then, the government has begun to change its strategy to tackle the problem of poverty in Indonesia, namely through Direct Cash Assistance (BLT), collateral for staples, and subsidies for staples (Daly, A., \& Fane, 2010). Later in the 2000s, the government began providing health insurance, also known as ASKES. However, these programs only reach 30 percent of the poor in Indonesia (E. Morrell, 2010).

The rise of poverty and the inability of the government to provide social security to the community became an important factor in the emergence of philanthropic organizations during the New Order and reformation. During the New Order era, President Soeharto appreciated the formation of the National Amil Zakat Agency (BAZNAS), to collect zakat funds among Indonesian Muslims (Salim, 2008). Non-governmental 
Islamic charity institutions have also emerged, such as Dompet Dhuafa, Community Care Justice Post (PKPU), Rumah Zakat, and zakat fund management, initiated by two mainstream Islamic organizations such as Nahdlatul Ulama (NU) and Muhammadiyah. Later, the zakat initiative communities began to mushroom in big cities such as the Simpul Alms, Alms group, Street Alms, and others.

Many scholars underline that the emergence of philanthropic institutions as above fills the vacuum and uncertainty of social service guarantees from the government (Benthall, 1999; Sakai, 2012; Retsikas, 2014). However, this argument needs to be examined again, is it true that the emergence of these philanthropic institutions is merely helping the government in providing social security to the community or there is another trend that Sakai calls because of the Muslim middle class and above who are trying to display their Islamic identity to the public sphere (Sakai, 2012).

\section{b. The Terrace of Dakwah and Social Generosity}

Amid Islamic philanthropic organizations struggling to serve and assist the poor with their respective service models, one of the Dakwah movements in Yogyakarta, Dakwah Terrace participated in responding to social welfare issues in the local, Yogyakarta and outside the region of Yogyakarta. Dakwah Terrace is a religious social institution based in the Nitikan Village, Yogyakarta. The name of the Dakwah Terrace is taken from the place of study, which is on the terrace of the house. Philosophically, the choice of the name "Dakwah Terrace," because the word "terrace" shows flexibility, simplicity, and not binding. In this case, ordinary people who do not have a strong Islamic religious background or people who want to study Islamic religious knowledge are not "reluctant, inferior" or "rigid" to join the Dakwah Terrace, so that in the end the Dakwah Terrace can become a unifying place for the Ummah across the harokah (Triantoro, 2018).

Through the initiative of Akhid Subiyanto and his colleagues, in 2011, the Dakwah Terrace began to hold religious studies on a $2.2 \times 12$-meter 
terrace. The religious study is routinely carried out every Wednesday by adopting the Islamic Community Boarding School (PMJ) propaganda pattern (Triantoro, 2018). In the Instagram story @terasdakwah, the Teras Dakwah claims that they always do the Koran recitation every Wednesday under any circumstances. In the story it says:

"There was also a time when Mount of Kelud in East Java erupted big, the Jogja Abu rain was quite thick, and Jogja was covered in dust everywhere, Jogja almost paralyzed its activities. But our study is not low! Wushh, TD continues to conduct a study 2 days after the first ash rain if I remember correctly on February 18, 2014. In a make-shift situation and after the yard was cleaned of dust we still held a Wednesday study, even though the congregation was not as usual but it still proceeded. Masyaallah, so it moved, why does it keep getting to the point of 'ngotot' but there's a study, isn't it just a day off? Yes, for us it is a matter of practicing istiqomah, when there is a rhyme that there is always a study, then no matter what if God still permits us to conduct a study, we will do as much as we can". https://www.instagram.com/stories/highlights/18008603026069 459/?Hl=en.

Based on the story above, the paradigm built by the Dakwah Terrace is the paradigm of thinking "istiqomah." In turn, that paradigm brought the Dakwah Terrace to an active dakwah movement to date. From year to year, the enthusiasm of the community to attend religious studies in the Dakwah Center is increasing. In 2011-2012, the number of worshipers who attended was only between 3-5 people. Then in 2013, 50-70 people attended the study. On February 22, 2014, Teras Dakwah decided to become a legal entity as a religious social institution engaged in community propaganda by notarial deed No. 02/22-Feb-2014. Thanks to this legal entity, Teras Dakwah can legally raise funds to develop its institutions from donors (Triantoro, 2018).

The programs initiated by the Dakwah Terrace are very diverse. Ngaji Teras, for example, this program is routinely carried out every week. The study themes raised also varied from the themes of religious studies, young people, economics, mysticism, and others. The themes of this study are packaged with popular narratives such as the title study of Married, Unmatched Mate, There is Dakwah on the Terrace of Love, Asking Ustaz, The Power of Giving, Blessing Will Not Be Swapped Like Snap Clasps, Let be Pious but Funky and 
others. In addition to the Teras Ngaji program, Teras Dakwah also initiates Creative Ngaji programs such as workshops and talkshows that discuss how to do business on the Internet, film surgery, Thibbun Nabawi treatment, and others (Triantoro, 2018).

As a religious social institution, Teras Dakwah does not only initiates programs in the form of religious studies but also actively engages in social service programs in the community. The next part will discuss the idea of a charity initiated by Teras Dakwah.

\section{c. Dakwah Terrace and its Charity Ideas: Local and Trans-local}

As seen in the caption of the Instagram @terasdakwah account in the introduction to this article, this article has shown how the involvement of the Dakwah Terrace in the efforts of social services, especially in responding to communities affected by floods in Bantul district, Yogyakarta, and other affected areas in Indonesia. As reported in the news in several online mass media, seconds.com, for example, explains that on 17 March 2019 several regions in Bantul and Yogyakarta districts were rained down with heavy rain all day. This has caused many rivers to overflow and flood people's homes. One of the areas hard hit by this flood was Imogiri, Bantul, because of its geographical location which is close to the Oya River and other small rivers (Detiknews., 2019).

In an Instagram post @terasdakwah that was uploaded on March 19, 2019, several volunteers who were part of the TD Mobile movement distributed donations in the form of staples to the community in the Mojolegi, Karangtengah, Imogiri, Bantul regions. This matter shows that the philanthropic activities initiated by the Dakwah Terrace are included in the charity-based missionary activism. Some scholars equate the term charity with traditional philanthropy, namely philanthropic activities to help disadvantaged people who are direct and short-term in fulfilling urgent needs (Fauzia, 2016).

This is different from generosity activism promoted by modern social service institutions such as Dompet Dhuafa, for example. Generosity activism promoted by Dompet Dhuafa tends to emphasize the practice of modern philanthropy, namely philanthropic activities that are empowering, 
mentoring, and long-term in nature like the empowerment of Bawang farmers in the Kulim area, Pekanbaru, Riau, the Dayun Livestock Village program, the empowerment program for goat farmers in Pangkalan Village, Dayun Village, Dayun District, Siak Regency. These programs showcase the practice of modern philanthropy. Although in other programs, Dompet Dhuafa is also involved in charity activism, for example helping flood victims in Kampar, Riau, humanitarian assistance for Rohingya, and others. However, the tendency of philanthropic institutions such as Dompet Dhuafa is more on modern philanthropic activism in The Drafting Team of Dompet Dhuafa Annual Report (Tim Penyusun Laporan Tahunan Dompet Dhuafa Riau, 2018; Tim Penyusun Laporan Tahunan Dompet Dhuafa Riau, 2019).

Charity-based propaganda activism carried out by the Dakwah Terrace can also be seen from the food distribution program for the elderly, widows, and poor people. In the first post posted on September 7, 2018, the food distribution program was called the Friday alms blessing. In this post, elderly Muslim women were seen listening to tausyiah before receiving food assistance from the Dakwah Terrace, as shown in Figure 1.
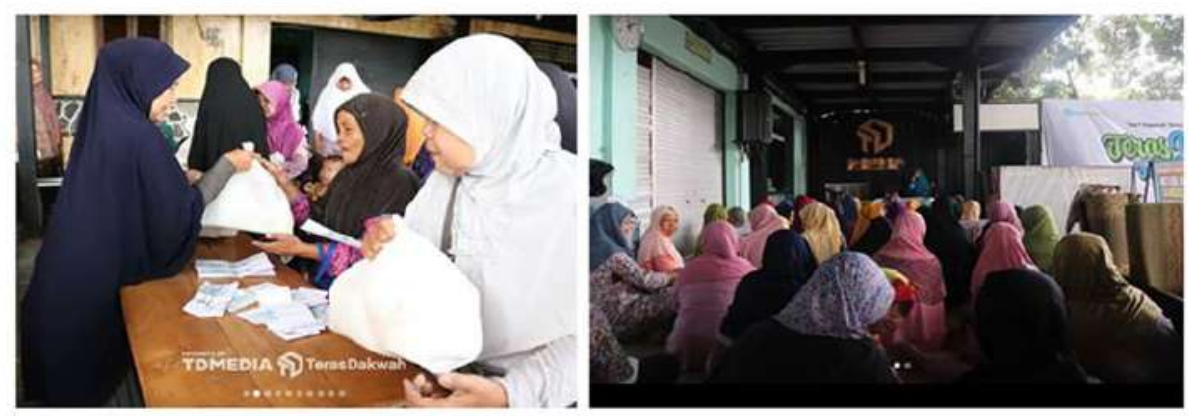

Figure 1: Sedekah Jumat Barokah Programme for Elderly, Widow, Poor, and Dhuafa

In addition to charity-based propaganda activism in the form of direct assistance in areas affected by the disaster and direct assistance for the elderly, widows, poor and disadvantaged, the Teras Dakwah through the Teras Qurban program slaughtered sacrificial animals in the Samigaluh area, Kulonprogo, Yogyakarta. The program is carried out in collaboration between the Dakwah Terrace and the Tameng Dakwah community, a 
Masduki et al.

Dakwah community in the Kulonprogo area, Yogyakarta. In their Instagram post, Teras Dakwah said that before the slaughtering event, they invited the community to join a study.

Starting from the basic food distribution program for widows to the Terrace of Sacrifice program, it shows that the Dakwah Terrace packed its missionary mission with charity-based activism. This is demonstrated through the way it channels its charity programs. In contrast to other philanthropic institutions which tend to provide direct social assistance, the Dakwah Terrace starts its charity program with religious studies with the community.

Some of the above charity programs are charity programs distributed in the local realm of Yogyakarta. The Dakwah Terrace is also involved in responding to socio-economic problems outside the Yogyakarta regions. The Teras Dakwah with its tagline TD Moving was actively also involved in assisting the victims in Lombok. One program that was touted massively was the construction of the mosque.

Based on the researchers' netnographic work, the mosque development program was mostly posted by Teras Dakwah through its Instagram account. The argument developed by Teras Dakwah about why it made a charity program, which led to the construction of the mosque, was to strengthen the Islamic faith of the people in Lombok and others after the earthquake. Furthermore, in the aftermath of a disaster the community usually experiences challenges of faith, which one of the citizens mentioned in the comment room is the emergence of Christianization discourse. Therefore, to answer that challenge, a mosque is needed as a means to strengthen the faith of the people in Lombok and others.

"Why Musholla (Small Mosque)? To maintain the Aqeedah of Muslims there today, there are many challenges after the earthquake, not only logistical but also Ruhiyah needs to be considered, Aqidah must remain upright despite the disaster. Residents will continue to maintain prayers, children's Qur'an learning activities will not stop, and the center of community activities is centered in this Musholla." https://wwwinstagram.com/p/BnASO7yntSO/?Utm_source=ig_web_copy_link 
One of the @terasdakwah Instagram account posts describes how they built a mosque in the area affected by the Lombok earthquake. By bringing a team of volunteers from Yogyakarta and synergizing with the community and other local dakwah communities, Teras Dakwah built many mosques made of lightweight steel. Charity program funding in the form of the construction of the mosque was obtained through the donors of the Dakwah Terrace and community contributions. In addition to funding, the naming of the mosque is also very diverse. For the mosque which was built by the Dakwah Terrace it self and is a new mosque construction, for example, it was named the Dakwah Terrace Mosque.

However, the construction of mosques in collaboration with certain communities or companies does not use the name of the Dakwah Terrace. As a collaboration between the Dakwah Terrace and the Friends of the Hijrah community, for example, the mosque they built was named the Silaturahim Mosque. Then the mosque builder in the Murpayung Daya, Sigar Penjalin Village, North Lombok, for example, the mosque was built by the Dakwah Terrace in collaboration with the international company Herba Penawar Al Wahida (hpa), a halal product company led by Mr. Haji Ismail bin Haji Ahmad in Malaysia. The mosque was formed by the collaboration of the two communities named the An-Nur Mosque. Then the Qomarul Huda Mosque in Cupek, Tanjung, North Lombok, this mosque was built by the Dakwah Terrace and Waroeng Steak and Shake.

Later, the earthquake and tsunami that struck Palu, Central Sulawesi, became the next concentration of Dakwah Terrace, to carry out charity-based missionary activism in the same pattern as in Lombok. They massively held a mosque construction there. In an Instagram @terasdakwah post, uploaded on December 26, 2018, they featured a temporary mosque building, the Al-Abrar Mosque that was built in collaboration with the Dakwah Terrace and the One Care community. Then in an Instagram post @terasdakwah that was uploaded on February 26, 2019, Teras Dakwah showed its charismatic activism that led to the formation of a new 
devotional space in Voro Loro, Alindau Village, Sindue Tobata District, Donggala, Central Sulawesi. The post not only shows the construction of the mosque carried out by the Dakwah Terrace with other dakwah communities as before. However, according to the post's caption, Teras Dakwah said that in the last 15 years, at that location, a mosque had never been built.

"Alhamdulillah ... Get together! Ar Rahman Mosque in Dusun V Loro, Desa Desa Alindau, Sindue Tobata District, Donggala, Sulawesi. This location is from the city of Palu about 2-3 hours. The epicenter of the earthquake, yesterday was about $20 \mathrm{~km}$ away. In this location, there is no mosque. Alhamdulillah, after 15 years, I didn't hear the call to prayer, starting today, it was heard again, the prayer time is 5 days" https://www.instagram.com/p/BuV_dJDlIZr/?Utm _source=ig_web_copy_link

The above caption shows that the mosque construction program initiated by the Dakwah Terrace, in turn, was not only a charity activity but also opened a new devotional space outside the Yogyakarta region. In addition to carrying out charity activism in the form of physical assistance, Teras Dakwah also helps the community in the form of strengthening Islamic values. In an Instagram post @terasdakwah, Teras Dakwah shows recitation activities led by Ustaz Awan Abdullah, a cleric from Yogyakarta who often fills studies on the Dakwah Terrace. He is also a caregiver of Majelis Taman Surga, a household counseling and taaruf community in Yogyakarta. According to Teras Dakwah, the strengthening of Islamic values needs to be given to people affected by the earthquake disaster in Lombok, so that they can face the calamity that is happening.

In a global context, Teras Dakwah is involved in channeling its charity program to Palestine. In a post, Dakwah Terrace showed photos of several Palestinian children accompanied by their parents receiving help from Dakwah Terrace which was represented by the Sahabat Al-Aqsa community, a Dakwah community in Indonesia focused on assisting the Palestinian people, as seen in Figure 2. 


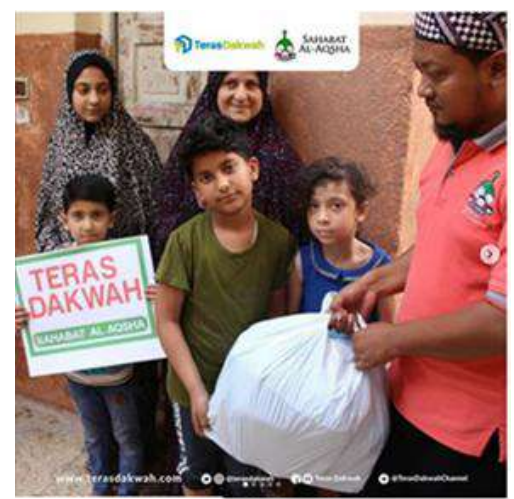

Figure 2: Aid Distribution of Dakwah Terrace for Palestina

\section{Discussion}

\section{a. The Dakwah Terrace and Charity-based Propaganda Activities}

Charity-based propaganda activities carried out by the Dakwah Terrace above, ranging from direct assistance in the form of staples for widows, the poor, and the underprivileged (in the Alms Friday Barokah program) or assistance for Palestine, sacrifice, construction of mosques/ mushala (small mosque) to strengthening Islamic values (spiritual support) illustrates a deep philosophy. At least from these programs, Dakwah Terrace has philosophical concepts including First, the charity program as a dakwah concept, which is a paradigm to form or strengthen the piety of the Islamic community, especially people in the affected areas. This is because in essence preaching is an effort to invite people to reach the ultimate level of piety. Second, the charity program as a concept of compassion. This concept is packaged in the slogan "Sharing Taste, Sharing happiness, and Sharing Smiles" (https://www.instagram.com/p/BvexTMklZYI/).

Third, the charity program as a concept of happiness, which by the Dakwah Terrace is called Sharing Happiness (Triantoro, 2018) (https://www.instagram.com/p/BvVgV7clEkb/). Fourth, the charity program as a concept of expediency, or among the activists of the Dakwah Terrace known by the tagline "Migunani Kagem Umat" (benefits for the people) (https://www.instagram.com/p/ Btuw7IFFalC/). For more details, see table1 below. 
Masduki et al.

Table 1: Charity philosophy on Terrace Dakwa's charity program

\begin{tabular}{ccc}
\hline No. & \multicolumn{1}{c}{ Charity Behavior } & \multicolumn{1}{c}{ Philosophy of Generosity } \\
\hline 1. & Construction of Mosque/ Mushala & $\begin{array}{l}\text { As a dakwah concept to form or strengthen the piety } \\
\text { of the Islamic community, especially the people in the } \\
\text { affected areas. }\end{array}$ \\
2. & Direct HelpAlms Barokah Friday & $\begin{array}{l}\text { As a concept of compassion (compassion) in the slogan } \\
\text { "Sharing Taste, Sharing Happiness and Sharing Smiles." } \\
\text { As a concept of happiness, known as Sharing Happiness } \\
\text { 3. }\end{array}$ Humanitarian Aid for Palestine \\
4. & Spiritual support & $\begin{array}{l}\text { As a concept of benefits known as the tagline "Migunani } \\
\text { Kagem Umat" (benefits for the people). }\end{array}$ \\
\hline
\end{tabular}

\section{b. The Dakwah Terrace and Social Media: Means of Constructing and Promoting Its Charity Idea}

The Dakwah Terrace massively uploaded posters inviting citizens to help disaster victims in various regions, both local and outside the Yogyakarta regions. The posters are interestingly packaged and illustrate the condition of the affected area, as shown in Figure 3.
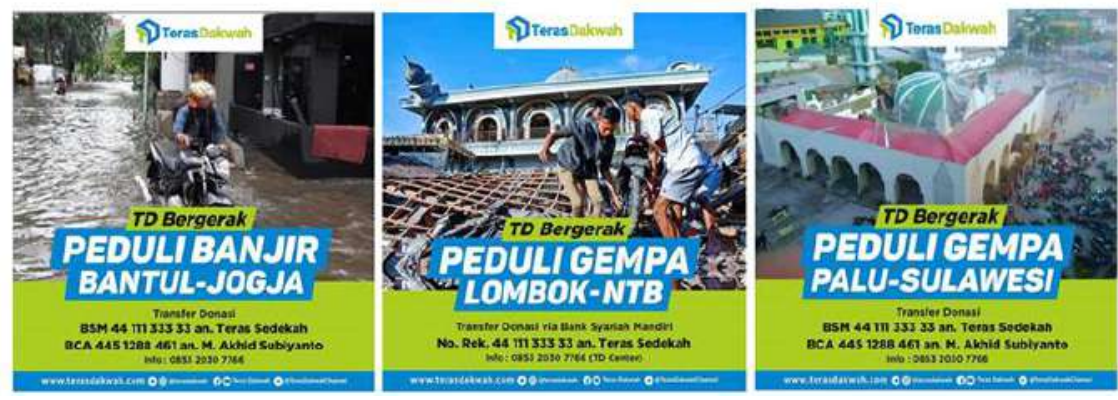

Figure 3: Karitas Poster of Dakwah Terrace

Images displayed by the Dakwah Terrace above illustrate what is called by Anderson (2006) with terms imagined communities which brings the audience as if they were in the community. In the context of Anderson, the news article (news article) can unite the people of the nation-state (nation-state) in different regions.

In addition, the pictures above are accompanied by a caption that tells the situation in several places affected by the disaster. For Bantul-Jogja Floods, for example, the poster is accompanied by the following captions:

"Innalillahi wainnailaihi raji' un on the night of March 17, 2019, 2 days of rain almost all day made some areas of Yogyakarta affected by flooding due to 
overflowing river water, even some landslides. Until now the number of losses is still not recorded perfectly, still in the process of evacuation $\mathcal{E}$ data collection. Until March 18, 2019, there have been subsided but there are still many areas that have been flooded, TD with our efforts tries to help and channel aid to the victims as much as we can..." (https://wwww.Instagram.Com/p/BvjjYJeF4he/?Utm_source=Ig_web_copy_link, n.d.)

The above caption further strengthens what Anderson calls the imagined community. By displaying images that seemed to be brought to the situation of the disaster area with the support of the storyline of the situation there, the writer assumes the poster can create an imagined community in the landscape of community generosity in Indonesia.

In addition to posters, Dakwah Terrace also promoted the idea of his charity in the form of a short video. Video of the construction of the House of Tahfidz of Teras Dakwah in Dusun Sire, North Lombok, for example, this video shows the activities of Muslim children who are reciting the Qur'an. Then the founder of Teras Dakwah, Akhid Subiyanto explained the activity. In the video that is approximately one minute long, Akhid said:

"Assalamualaikum bro, here I am in the North Lombok Dusun Sire. And these children (while pointing at the children who are reciting) are our potential that God willing will later fill in the House of Tahfidz of Dakwah Terrace that we are building. And they became pioneers, pillars of our dakwah in north Lombok. Insha Allah. We hope that this alms can become a charity for all ladies and gentlemen. thanks" (https://www.Instagram.Com/p/BwhjjONlr80/?Utm_ Source $=$ Ig_web_copy_link, n.d.) $k$ )

Then at the end of the video, the Dakwah Terrace lists account numbers for donors. This short video uploaded on April 21, 2019, received the attention of citizens. One of the citizens @tatyakemayuningsih asked again for the account number that can be used to distribute donations. This shows that social media is very likely to promote the idea of charity in the current era.

The Dakwah Terrace uses social media to disseminate the details of the charity proposal. They explained the materials for making the mosque, 
Masduki et al.

the size of the mosque to be built, and the costs needed to build a mosque in Lombok. In addition, Dakwah Terrace also explained the time needed to build a mosque in Lombok. Then they also include the account number for donations, as shown in figure 4.

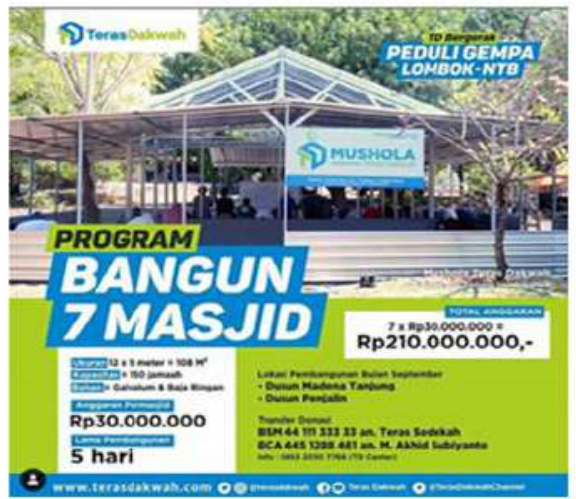

Figure 4: Proposal Poster of Mosque Construction

In contrast to the charity proposal poster above, in a short video uploaded to its Instagram account, Teras Dakwah used its charity program to get involved in political discourse in Indonesia recently. The video uploaded on April 20, 2019, featured two Teras Dakwah volunteers who were calculating the cost of building the mosque. In addition, this 51-second video is titled "Real Quick Count" caption. In the video, a volunteer calculates the budget for financing mosque construction materials for 54 million. Meanwhile, another volunteer said that the calculation done by his best friend was wrong and very fast. He also likened the miscalculation to the budget as the calculation of the Quick Count.

The matter above shows that the Dakwah Terrace responds to the discourse of politics in Indonesia. In that year the discourse of politics in Indonesia, especially the presidential election, has experienced very significant voter fragmentation. It could be said that there was resistance from the two big camps, between the Jokowi and Prabowo camps. To the authors' knowledge, based on fieldwork on the Dakwah Terrace, the researchers follow religious studies filled by Ustaz Haikal Hasan, an Ustaz affiliated with the Indonesian Ulema Council Fatwa Guard (GNPF-MUI) 
and is very "vocal" to voice support for Prabowo. In the study, political narratives were strongly conveyed by Ustaz Haikal. Therefore, the researchers assume that the video upload with the caption of the Real Quick Count also shows how the Dakwah Terrace is trying to get involved in the Quick Count issue submitted by the Election Commission (KPU). The Quick Count results issued by KPU have become a controversial issue in the community these days. The Dakwah Terrace also voiced the error, mainly by utilizing its charity program in Lombok.

To promote the idea of charity, the Dakwah Terrace also uses reward narratives for those who want to finance the construction of mosques in areas affected by the earthquake and tsunami. In a video posting on the account Instagram @terasdakwah, Kang Ruslan, a commander of the Teras Dakwah mosque construction said:

"We, as representatives of Dakwah Terrace and Muslim United say many thanks to all the people who have united to build the mosque. In a hadith it is mentioned, that whoever builds a mosque even if it is only as big as an anthill, Allah will make a house in Heawen" (https://uww.Instagram.Com/p/BuWWFrljbw/?Utm_source=ig_web_copy_link,nd.).

This shows what is called by Marcel Mauss as awarding the prize economic theology, the activity of generosity. It believes that everything we are given will result in a reward in the next life. The gift is not lost, but instead will develop and increase (Mauss, 2002).

Teras Dakwah, not only promotes its ideas of charity, but it also uses social media to build its image as a professional missionary institution in packaging charity programs. It massively uploaded its charity activities to gain public trust. In the charity program in Lombok, for example, Dakwah Terrace uploads videos of its journey from the departure at the airport, arriving at the destination airport, to completing the construction of the mosque. Teras Dakwah uploaded a video of the departure of Teras Dakwah volunteers to Lombok. This 1-minute video features the journey of the Dakwah Terrace to Yogyakarta's Adi Sutjipto Airport. Then it shows the 
volunteers being checked-in, boarding the plane, until arriving at Lombok Airport. In the video recorded at Lombok Airport, Akhid said:

"Assalamualaikum, my friends, thank God, we are with the Teras Dakwah team. The TD Mobile has arrived in Lombok this morning healthily and smoothly. And we will go directly to our post, in Dusun Sire, Tanjung District, North Lombok with Ustaz Awan Abdullah. Yo wis, assalamualaikum." (https://www.Instagram.Com/p/Bm0pDnKnb5O/?Utm_source=ig_web_copy_l ink, n.d.)

Then during the mosque construction process, Teras Dakwah also uploaded photos and videos to its Instagram account @terasdakwah. In a video, a Teras Dakwah volunteer recounts the development of a mosque in northern Lombok.

"Assalamualaikum warahmat ullahi wabarakatuh. Alhamdulillahirobbil Alamin, currently, is the second day of the construction of the mosque in Tanjung Island, $K L U$, North Lombok. Currently, team 2 is working on roofing and pillar casting. Let's Pray that today the team will not be constrained by the weather." (https://www.Instagram.Com/p/BvbYMZhlo8A/?Utm_source=ig_web_copy_lin $k$, n.d.).

Almost all of the distribution activities of charity uploaded by Dakwah Terrace into their social media accounts, especially Instagram, as shown in Figure 5.
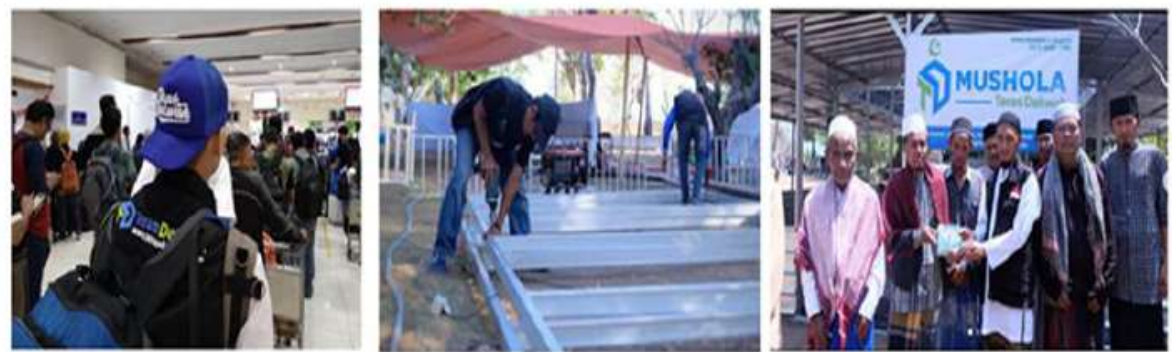

Figure 5: Departure, Making, and Distribution of Dakwah Terrace Aid

The explanation in this sub-chapter shows that the Dakwah Terrace is very professional in using social media as a means of promoting the idea of charity and building image in the online space. Sule \& Sulaiman (2021) explains that social media is a workable and genuine tool for the 
propagation of ideas of Islam. Through the TD Media Team, which is driven by young Muslims in Teras Dakwah, the Teras Dakwah charity programs are packaged in an interesting and "political" way. In addition, social media is an important concern for the Dakwah Terrace. This can be seen from some preaching study programs focusing on the media such as the study entitled "Medsosku my gun" which was held on 27 April 2019. The study program entitled "Me + He Islamic Journalism Islam and the Role of Young Generation," was held on February 6, 2019, and so on. When the Dakwah Terrace conducts monthly evaluations, one of the focuses of Dakwah Terrace is on strengthening the media, primarily to realize Dakwah 4.0. With the 4.0 dakwah model, it hopes to be involved in combating heretical thoughts, evil narratives, and hoaxes in cyberspace (https://www.Instagram.Com/p/Bv89FNMltb7/, n.d.).

\section{Conclusion}

Through the case study on the Dakwah terrace in Yogyakarta, this article shows two points. The first is that the dakwah in Indonesia has been intensively done and expanded. It is now no longer limited to oral activities and propaganda. However, in its development, Dakwah also led to the activities of Islamic generosity (charity). The Dakwah Terrace's involvement in charity programs has shown that the dakwah movement can compete with the Islamic charitable institutions such as Dompet Dhuafa, Simpul Sedekah, and Sedekah Rombongan.

Secondly, the rise of digital technology such as social media has supported the growth of dakwah in Indonesia. Social media has become the main vehicle for the Dakwah Terrace to promote the idea of its charity and build its image as a professional social institution. The whole process of his charity is echoed through interesting uploads on his Instagram media account. In turn, it succeeded in bringing its charity programs into social media trends.

Through this study, the authors recommend future studies to see the significance of the dakwah movement in Islamic political discourse in Indonesia. Although, in this study, little was touched, but not yet deep 
Masduki et al.

enough. To the authors' knowledge, studies that carry out about contemporary dakwah movements and Islamic politics or political Islam do not yet exist.

\section{Bibliography}

Anderson, B. R. O. (2006). Imagined communities: reflections on the origin and spread of nationalism (Rev. Ed). Verso.

Benthall, J. (1999). Financial Worship: The Quranic Injunction to Almsgiving. The Journal of the Royal Anthropological Institute, 5(1), 27. https://doi.org/10.2307/2660961

Bustamam-Ahmad, K. (2019). The Religious Imagination in Literary Network and Muslim Contestation in Nusantara. Jurnal Ilmiah Peuradeun, 7(2), 217-244. doi:10.26811/peuradeun.v7i2.344

Daly, A., \& Fane, G. (2010). Anti-Poverty Programs in Indonesia. Bulletin of Indonesian Economic Studies, 38(3), 309-329. https://doi.org/10.1080/00074910215535

Detiknews. (2019). Hujan Deras Air Sungai di Bantul Meluap. Detiknews. https://news.detik.com/berita-jawa-tengah/d-4471553/hujanderas-air-sungai-di-bantul-meluap

Dhuafa, D. (2018). Annual Report 2017.

Dhuafa, D. (2019). Annual Report 2018.

Fauzia, A. (2016). Filantropi Islam: Sejarah dan Kontestasi Masyarakat Sipil dan Negara di Indonesia. Gading Publishing.

Hasan, N. (2007). The Salafi Movement in Indonesia: Transnational Dynamics and Local Development. Comparative Studies of South Asia, Africa and the Middle East, 27(1), 83-94. https:/ / doi.org/10.1215/1089201x-2006-045

Hoesterey, J. (2008). Marketing Morality: The Rise, Fall and Rebranding of Aa Gym. In G. F. \& S. White (Ed.), Expressing Islam: Religious Life and Politics in Indonesia (pp. 95-112). ISEAS Publishing. https://doi.org/10.1355/9789812308528-010

https://www.instagram.com/p/Bm0pDnKnb5O/?utm_source=ig_web_copy_link. (n.d.). https://www.instagram.com/p/BnASO7yntSO/?Utm_source=ig_web_copy_link.(2017). https://www.instagram.com/p/BuV_dJDlIZr/?Utm_source=ig_web_copy_link.(2017). 
https://www.instagram.com/p/BuVW-fzlj8w/?utm _source=ig_web_copy_link. (n.d.).

https://www.instagram.com/p/BvbYMZhlo8A/?Utm_source=ig_web_copy_link.(n.d.). https://www.instagram.com/p/BvjjYJeF4he/?utm_source=ig_web_copy_link.(n.d.). https://wwww.instagram.com/p/BwhJjONlr80/?Utm_source=ig_web_copy_link.(n.d.). https://www.instagram.com/stories/highlights/18008603026069459/?Hl=en.(2017). https://www.instagram.com/p/Bv89FNMltb7/. (n.d.).

Kailani, N. (2012). Forum Lingkar Pena and Muslim Youth in Contemporary Indonesia. Review of Indonesian and Malaysian Affairs, 46(1), 33-53. https://doi.org/10.3316/informit.984332214396280

Kozinet, R. V. (2010). Netnography: Doing Ethnographic Research Online. SAGE Publications.

Mauss, M. (2002). The Gift: the Form and Reason for Exchange in Archaic Societies. Routledge Classics.

Morrell, E. (2010). Balancing Livelihoods, limited options, and the State: Alleviating Poverty in Critical Environments (H. C. \& E. Morrell (Ed.)). Routledge.

Nasor, M., Ngisomuddin, \& Alamsyah, Y. A. (2019). Nasor, M.; Ngisomuddin, Ngisomuddin; Alamsyah, Yosep Aspat. Community Empowerment through Mentari Baitul Mal Wat Tamwil (BMT) to Boost Muslim Family Economy in Kotagajah Central Lampung. Jurnal Ilmiah Peuradeun, 7(3), 569-588. https:// doi.org/10.26811/ peuradeun.v7i3.440

Patimah, S., \& Tabrani ZA. (2018). Counting Methodology on Educational Return Investment. Advanced Science Letters, 24(10), 7087-7089. https://doi.org/10.1166/asl.2018.12414

Retsikas, K. (2014). Reconceptualising Zakat in Indonesia. Indonesia and the Malay World, 42(124), 337-357. https:/ / doi.org/10.1080/13639811.2014.951519

Rosidi, I. (2021). Da'wah and Politics Among Muslim Preachers in Contemporary Indonesia. Intellectual Discourse, 29(1), 35-52.

Sakai, M. (2012). Building a partnership for social service delivery in Indonesia: state and faith-based organizations. Australian Journal of Social Issues, 47(3), 373-388. https:// doi.org/10.1002/j.1839-4655.2012.tb00254.x

Salim, A. (2008). The Shift in Zakat Practice in Indonesia: From Piety to an Islamic Socio-Politica-Economic System. Silkworm Books. 
Masduki et al.

Schulz, D. (2012). Dis/Embodying Authority: Female Radio "Preachers" and the Ambivalences of Mass-Mediated Speech In Mali. International Journal of Middle East Studies, 44(01), 23-43. https:/ / doi.org/10.1017/S0020743811001231

Sofjan, D., \& Hidayati, M. (2013, September). Religion and Television in Indonesia: Ethics Surrounding Dakwahtainment. Globethics.Net.

Sofjan, D. (2012). Gender Construction In Dakwahtainment: A Case Study of Hati ke Hati Bersama Mamah Dedeh. Al-Jami'ah: Journal of Islamic Studies, 50(1), 57-74. https://doi.org/doi.org/10.14421/ajis.2012.501.57-74

Sule, M. M., \& Sulaiman, Y. (2021). Enhancing Da'wah and Spread of Knowledge Via Social Media Platforms. Jurnal Ilmiah Peuradeun, 9(1), 145-160. https://doi.org/10.26811/peuradeun.v9i1.549

Sunarwoto. (2012). Radio Fatwa: Islamic Tanya-Jawab Programmes on Radio Dakwah. Al-Jami'ah, 50(2), 239-278. https:/ / doi.org/10.14421/ajis.2012.502.239-278

Triantoro, D. A. (2018). Dakwah dan Kesalehan: Studi Tentang Gerakan Teras Dakwah di Kota Yogyakarta. Jurnal Masyarakat \& Budaya, 20(2), 273-286. https://doi.org/10.14203/jmb.v20i2.624

Walidin, W., Idris, S., \& Tabrani ZA. (2015). Metodologi Penelitian Kualitatif $\mathcal{E}$ Grounded Theory. Banda Aceh: FTK Ar-Raniry Press.

Watson, C. W. (2005). A Popular Indonesian Preacher: The Significance of Aa Gymnastiar. Journal of the Royal Anthropological Institute, 4(11), 773-792. https://doi.org/10.1111/j.1467-9655.2005.00261.x

Weng, H. W. (2018). The Art of Dakwah: Social Media, Visual Persuasion and the Islamist Propagation of Felix Siauw. Indonesia and the Malay World, 46(134), 61-79. https://doi.org/10.1080/13639811.2018.1416757 
p-ISSN: 2338-8617

Vol. 10, No. 1, January 2022 e-ISSN: 2443-2067 